
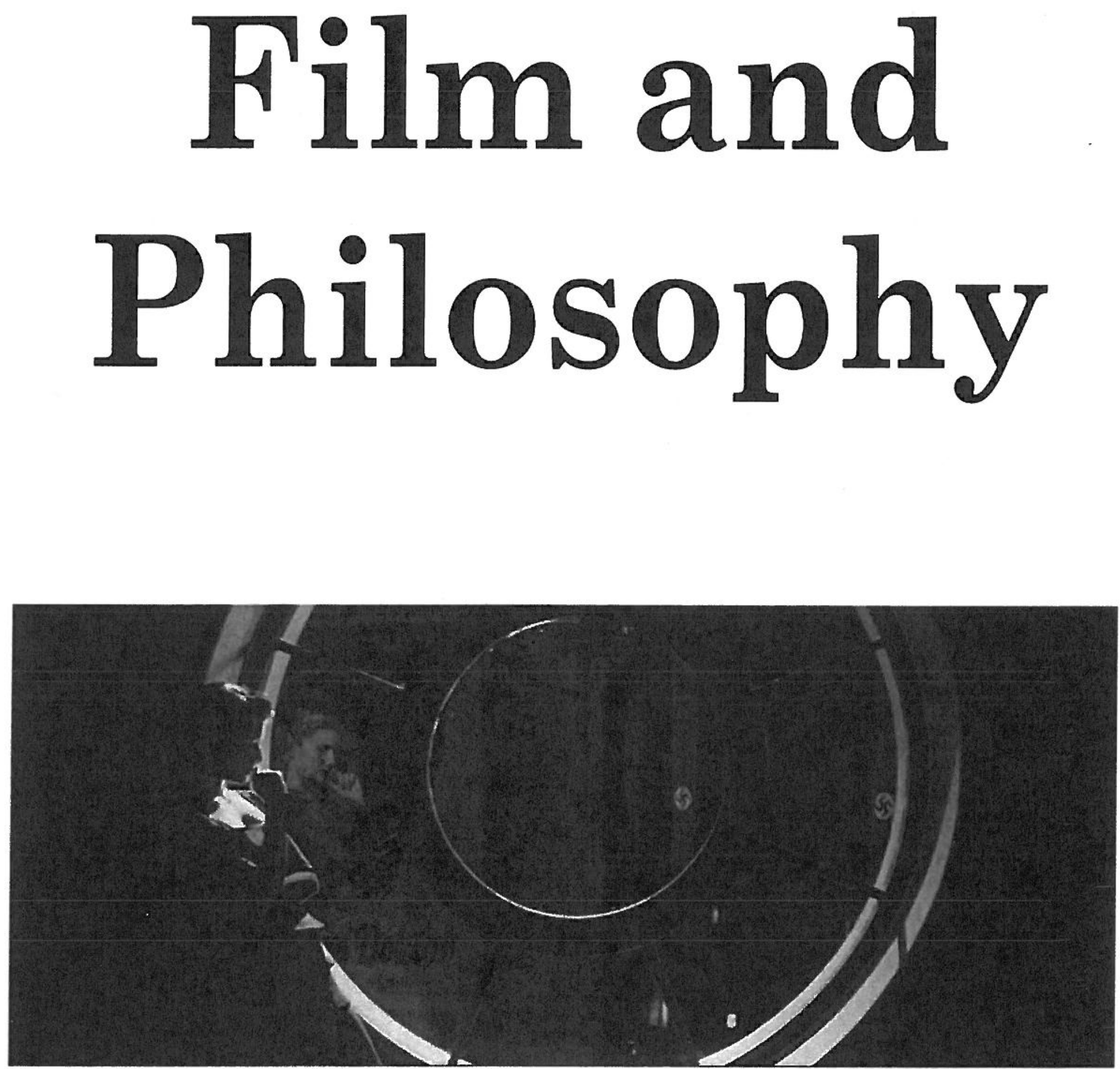

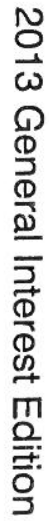

Volume 17 2013 General Interest Edition Dan Shaw, Editor 


\section{Ideology, Socratic elenchus, and Inglourious Basterds ${ }^{1}$}

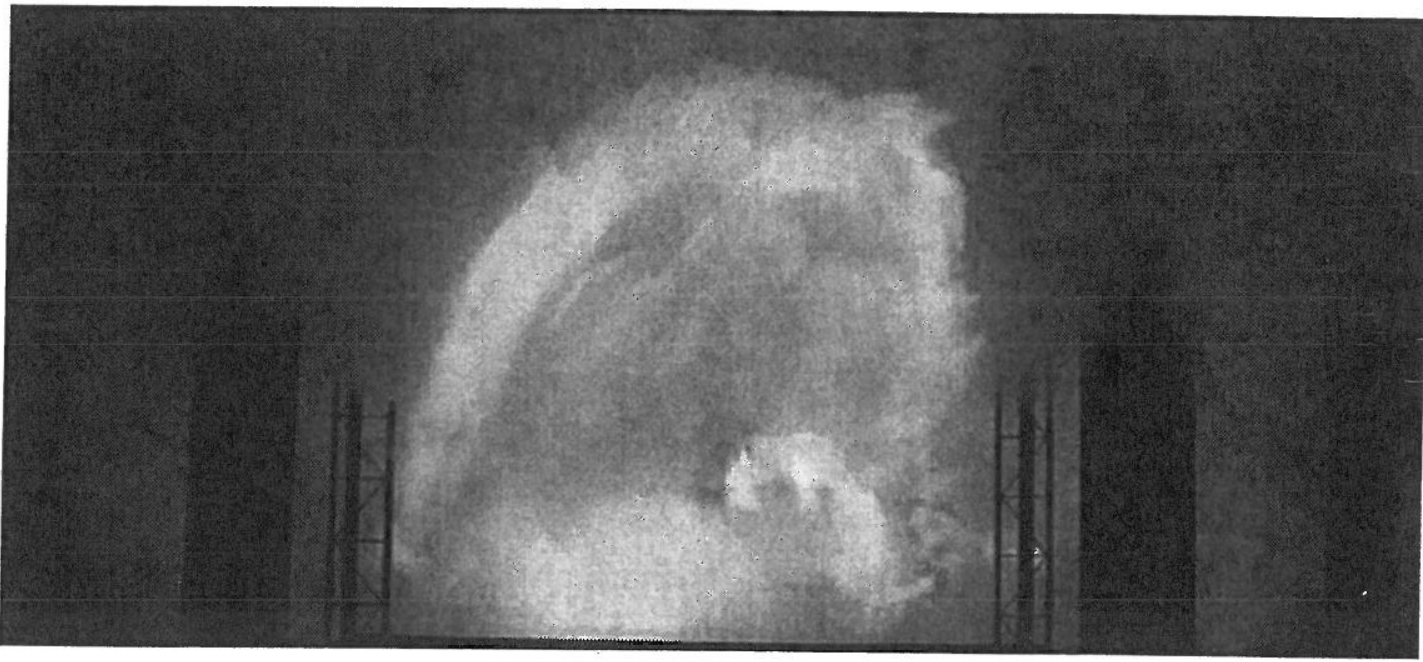

\section{Gadfly on the Mighty Steed of Hollywood}

The topic of ideology has figured prominently in discussions of Quentin Tarantino's Inglourious Basterds (2009). ${ }^{2}$ Tarantino's film both uses ideological tropes (about Native Americans, Nazis, and Jewish people, for example) and ironically distances itself from them at the same time. Nowhere is this dynamic more obvious than Tarantino's propaganda-movie-within-a-propaganda-movie device. Basterds employs the machinery of ideology by modeling itself on quasipropaganda war films (anti-Nazi) from the 1960s, '70s, and '80s, but at the same time it offers an intricate critique of such films (indeed, in Tarantino's movie Hitler is finally undone by his participation in the viewing of Nation's Pride, the fictional pro-Nazi propaganda war film). ${ }^{3}$ This duality forces us to ask whether Basterds's hip irony towards ideology is insightful, vapid, or worse.

"Vapid" is the answer posed by Daniel Mendelsohn." Mendelsohn considers the movie to be Tarantino's latest attempt at "post-modern fun" but he ultimately condemns it as an ill-advised use of Jewish suffering not just as popular entertainment but as an excuse to indulge in the visceral pleasures of revenge. ${ }^{5}$ "Worse" is Liel Leibovitz's answer, in his scathing analysis of the film. ${ }^{6}$ Leibovitz finds Tarantino's use of filmic irony and self-consciousness both a failure of aesthetics and a failure of morality; Tarantino's film offers a "cartoonish defeat" of the Nazis and it amounts to the exact same kind of shallow propaganda that Tarantino depicts in the aforementioned Nation's Pride. After likening Tarantino's film to Nazi propaganda, Leibovitz contrasts it with the work of "intelligent and sensitive directors" who have explored the issues of Nazism, the Holocaust, and 
ideology, citing several mainstays from the contemporary cinematic cannon: JeanPierre Melville's Army of Shadows (1969), Marcel Ophüls' The Sorrow and the Pity (1969), and Claude Lanzmann's Shoah (1985). To Leibovitz these films are "Talmudic" in their intricate investigations into the "fundamental questions of our species."

Contrary to the "vapid" and "worse" characterizations of the use of ideology in Basterds, the most persuasive defense of the "insightful" answer thus far has been offered by Eric Kligerman. ${ }^{7}$ Kligerman sets out to defend Basterds from Leibovitz's attack by arguing that the cinematic self-references of the film provide a layering of interpretations and tensions that is as complex as that manifested in Ophüls' The Sorrow and the Pity. Kligerman hence attempts to show that Tarantino's film can offer "Talmudic" reflections on Nazism and ideology on par with Ophüls' film.

In this essay, however, I defend a much stronger thesis: in my view, Basterds offers contemporary viewers critical insights into ideology that Ophüls' film simply cannot muster. Specifically, I argue that the key to understanding its use of ideology is Socratic elenchus: our unwitting participation in, and enjoyment of, ideological devices in the film is cross-examined by the abhorrent aspects of ideology that it depicts. Hence, Basterds leaves us in a sort of ideological aporia, which, I will claim, is an achievement that is both masterful and distinct from what is accomplished by Ophüls' classic.

\section{Leibovitz's Argument}

The Sorrow and the Pity is a two-part documentary on Vichy France that explores themes of resistance and collaboration. A combination of original interviews and re-appropriated newsreels, documentaries, propaganda, and fictional film clips, it served a significant historical purpose: exposing the involvement of many French collaborationists, at a time (the 1950s and '60s) when the "myth of resistance" to the Nazis dominated the national consciousness of France. ${ }^{8}$ The film thereby champions remembrance over ideology, even the anti-Nazi ideology of the French resistance.

One of the subtlest and most effective aspects of Ophüls' film is its treatment of judgment and retribution. This issue arises in many interviews conducted by the director. One former German soldier that Ophüls interviewed was stationed in France during the fall of the Vichy government. Injuries kept him bound to a stretcher as he awaited a train to take him back to Germany. He describes how 
the newly emboldened French citizens came by and spit at him as he lay there on the platform. When Ophüls asks him how it felt to be mistreated in that way, he replies: "I felt it wasn't very decent of the people there. It was disgusting, actually. They should have realized that we could have done the same to their father or son. What then?" In this episode, the German soldier (who is not portrayed very sympathetically) clearly demonstrates imaginative deficiency when he indicts the behavior of the French citizens as indecent and disgusting because they did not consider things from his perspective. The irony is obvious, given our knowledge of what the Germans did to the "fathers and sons" of those innocent citizens, acts far worse than spitting at an injured soldier.

Yet The Sorrow and the Pity does not ultimately endorse the spitting-its singular achievement is its ability to subtly raise difficult questions, forcing us to think about how one really should react to the events described. ${ }^{9}$ In another scene, a French resistance fighter (who is depicted sympathetically) explains why he did not mistreat the German soldiers that he was guarding. He says, "If I'd treated them the way they treated me, I wouldn't have been any better than them." This attitude serves as counterpoint to another segment in which Ophüls re-appropriates footage of Raymond Guyot, another resistance fighter (as well as French communist party member), speaking at a large rally, "In order for France to be liberated, every inch of our motherland must be cleansed of every Boche and every traitor." Ophüls' film exposes Guyot's cries for punishment and "cleansing" as morally dangerous without allowing the pendulum to swing in the contrary direction of forgive and forget. The simple answer that collaborators deserve harsh punishment begins, in Ophüls' treatment, to seem like a mere continuation of the violence and nefarious use of ideology that the resistance fighters were reacting against.

Herein lies the key point for critics of Basterds like Leibovitz, who contrast it with The Sorrow and the Pity. Tarantino's film centers on a band of American Jews on a mission to terrorize and maim German soldiers; they eventually perform a special mission to kill Hitler that ends with his execution, followed by the incineration of his body in a movie house whose doors are locked and barred like a gas chamber (as the haunting face of Shosanna Dreyfus/Emmanuelle Mimieux (Mélanie Laurent) projected on the smoldering screen chants, "This is the face of Jewish vengeance"). If seen merely as a revenge fantasy, Tarantino's film seems to succumb to the moral perspective that Ophüls has already exposed and found wanting. If so, Basterds has nothing of value to add to the converstion 
about ideology, Nazism, and the Holocaust. Leibovitz characterizes the difference between the two films as follows:

He [Tarantino] doesn't see cinema as a way to look at reality, but - ever the child abandoned in front of the television set, ever the video-store geek - as an alternative to reality, a magical and Manichean world where we needn't worry about the complexities of morality, where violence solves everything, and where the Third Reich is always just a film reel and a lit match away from cartoonish defeat. (Leibovitz 2009)

By contrast, Ophüls, Melville, and Lanzmann

use film not in order to set ablaze heaping mounds of flesh, but in order to try and understand the malice and complicity that led Europe to its benighted state. They do so because they realize that understanding - an act that requires us to learn and see evil not as a black monolith but as a gray composite of many small and often insufferable nuances-is our best claim to humanity, our last chance at grace. (Leibovitz 2009)

So, Ophüls helps us understand the human failings that led to Nazism and the Holocaust, while Tarantino's violence-solves-everything attitude simply succumbs to those failings. All the more worrisome, Tarantino rewrites history and the end of the war, which seems to make Basterds the antipode to Ophüls, whose purpose is memory and the correction of false history. So whereas Ophüls champions remembrance over ideology (even anti-Nazi ideology), Tarantino seems to champion ideology over remembrance. At one point in The Sorrow and the Pity, when a group of French resistance fighters discuss the worrying prospect of resurgent ideologies in a variety of disguises, one person remarks, "A rose by any other name is still a rose." To Leibovitz, it seems, Tarantino's film is just another rose. ${ }^{10}$

\section{Kligerman's Argument}

In contrast to Leibovitz, Kligerman sees much more continuity between The Sorrow and the Pity and Inglourious Basterds. Both films deal with themes of justice and revenge, and both use a complex network of inter-filmic references to expose the fantasies we all seem to prefer to inglorious reality. Ophüls exposes the fantasy of the French resistance, while Tarantino exposes the fantasy of shallow revenge. What Kligerman sees, and what Leibovitz missed, is that Tarantino's film does not advocate the fantastical escape from reality, but confronts us with our desire for such an escape.

Two mechanisms allow Basterds to function in this way. One is its rewriting of history. Rather than serving as an act of forgetfulness, the film's alternate ending 
to the war presents a challenge to traditional Holocaust discourse: "Through his brazen presentation of a counter-narrative to the Shoah and representations of Jews during the Holocaust, Tarantino dismantles the structures of Holocaust discourse, the reified modes of representing catastrophic history and Jews themselves, and provokes the spectator to think anew questions pertaining to these representations" (Kligerman 2012: 139). The other is Tarantino's nearly compulsive use of filmic references, which challenge us as spectators to engage with questions of representation and signification: "I would place Tarantino's filmic style in the very tradition of a Jewish hermeneutics that Leibovitz and others deny to him. There is indeed something Talmudic in Tarantino's approach to the interplay between the Shoah and cinema" (Kligerman 2012: 138). The result is that our desire for revenge is problematized, as we recognize the parallels between our revenge fantasy and the real violence we are reacting against. As spectators we are called to engage with the complicated series of references in the film and thereby begin the Talmudic process of meeting interpretations with further interpretations. ${ }^{11}$

Kligerman is particularly interested in the sexual nature of the revenge fantasy. He compares Woody Allen's film Annie Hall, which segues from Alvy and Annie's (Woody Allen and Diane Keaton, respectively) viewing of The Sorrow and the Pity to Alvy's sexual advances on Annie, with the stereotype of the "muscle Jew" or "tough Jew" and its incumbent sexual symbolism. The muscle Jew stereotype can be found, in addition to Basterds, in films from Munich (Steven Spielberg, 2005) to You Don't Mess with the Zohan (Dennis Dugan, 2008), but best of all for Kligerman's purposes is the meta-filmic moment in Knocked Up (Judd Apatow, 2007) when one character says to his friends, "Every movie with Jews, we're the ones getting killed. 'Munich' flips it on its ear-we're capping motherfuckers. Any of us get laid tonight, it's because of Eric Bana and Munich" (Kligerman 2012: 137).

Kligerman uses these references as a backdrop to analyzing reactions to Basterds that combine themes of sexualization and Jewish stereotypes:

As Tarantino remarked, "People might say I've gone too far, but I know for a fact Jewish people have been waiting for a WWII Jewish revenge movie for a long time." Calling the film "Kosher porn," Eli Roth, who plays the Bear Jew, described his act of machine gunning Hitler as "orgasmic"; the film's producer Lawrence Bender said to Tarantino, "As a member of the Jewish tribe, I thank you. This is a fucking Jewish wet dream"; Goldberg goes one step further and describes the film as an "unabashed wet dream of vengeance." (Kligerman 2012: 146) 
The sexual nature of revenge provides one of many ways in which Kligerman shows how an engagement with the complex series of filmic references and stereotypes in Basterds can call into question our simpleminded enjoyment of the film's exaggerated representations of Jews, the Holocaust and Nazism. In this way Tarantino's film, no less than Ophüls', provides the basis for a nearly endless hermeneutic investigation into justice, vengeance, and ideology.

\section{Ideology in Basterds}

Inglourious Basterds continues Tarantino's characteristic interest in genre conventions. ${ }^{12}$ His previous movies have reprised the heist film (Reservoir Dogs, 1992), the gangster film (Pulp Fiction, 1994), the Blaxploitation film (Jackie Brown, 1997), and the martial arts film (Kill Bill: Vol. 1 and Vol. 2, 2003 and 2004, respectively). Genre conventions are important because they generate ideologically laden stereotypes and create an ideological battlefield of good vs. evil with which the film can ironically interact. Most overtly, Basterds combines elements of two genres, the spaghetti western and the World War II action film.

The spaghetti western genre is signaled from the first "Chapter" of the film, subtitled "Once Upon a Time... In Nazi Occupied France," which invokes both Once Upon a Time in the West (Sergio Leone, 1968) and the fairy tale ur-genre. Chapter 1 of Basterds then opens with a French dairy farmer chopping wood on a landscape rendered like an old-west prairie. A group of Nazis approach ominously in the distance, recalling a group of government soldiers bearing down on the homestead of some Indian sympathizers (tough Jews as Indian savages is one of the fascinating ideological interplays of the film). Basterds's soundtrack even includes eight tracks from Ennio Morricone, who scored Once Upon a Time in the West in addition to many other spaghetti westerns.

Even more clearly than the spaghetti western, Basterds is modeled on war movies of the '60s and '70s such as Robert Aldrich's The Dirty Dozen (1967), J. Lee Thompson's The Guns of Navarone (1961), and Enzo Castellari's The Inglorious Bastards (1978) ${ }^{13}$, films which celebrate American and British heroism in World War II. ${ }^{14}$ All four of these films depict a band of misfit yet gifted Allied forces on a perilous mission against the Germans; in Tarantino's film, Lieutenant Aldo Raine (Brad Pitt) trains and leads a group of Jewish-Americans on a revenge mission against the Nazis. While The Dirty Dozen and The Guns of Navarone are not as blatant as Frank Capra's Why We Fight series (1942-1945), they share important features with Capra's institutionalized, government-funded propaganda: they 
champion the American military and American values at a time of international conflict (in the case of the '60s and '70s films: the general Soviet and communist menace; tension with East Germany; the erection of the Berlin wall; and, later, the war in Vietnam). ${ }^{15}$

Unlike The Dirty Dozen and The Guns of Navarone, however, Basterds is a self-aware film that ironically distances itself from its own ideological aspects. ${ }^{16}$ The film celebrates American war heroism and American values; e.g., the "Bear Jew" (Eli Roth) celebrates the American sport of baseball by using a baseball bat as execution device while spouting a euphoric fantasy of being Ted Williams. Yet the film both shows viewers that it realizes that it is ideologically laden (during the Bear Jew-baseball event Raine quips, this is "the closest we get to going to the movies") and invites them to laugh at ideological propaganda (e.g., at the self-satisfied-but-feigned-humility of Fredrick Zoller (Daniel Brühl), the German Private who became a war hero and nascent movie star by playing himself in the Nazi propaganda film Nation's Pride ${ }^{17}$ ).

This pattern, of simultaneously utilizing ideological tropes and ironically distancing itself from those tropes, is evident in a myriad of ways. Consider three other examples. First, the film depicts Hitler (Martin Wuttke) as a paranoid and self-conscious buffoon: when we are introduced to Hitler he is posing in a lavish kitsch robe for an over-sized (caricatured) wall portrait. Tarantino tells us that he knows he is depicting a funny and ridiculously exaggerated picture of Hitler by having a painter in the film depicting a funny and ridiculously exaggerated picture of Hitler.

Second, Basterds uses ideologically motivated stereotypes of Africans, African-Americans and Native Americans ${ }^{18}$, but the film also tells us that it knows that it (thus: ironically) uses such stereotypes. Consider, for example, how Africans and African-Americans are depicted in the cellar tavern scene in which several characters play a card game. In the game one is assigned an identity on a card; the card can be seen by everyone else but not by oneself; the goal is to guess one's identity by asking questions of the others. A Nazi officer is trying to guess that he is King Kong, and through a series of questions he learns that he is a large black beast taken in chains on a boat from his native jungle in Africa to America, where he meets with misfortune. At this point the officer deduces that he is either King Kong or a black person, and he asks whether he is real or fictional. We are supposed to enjoy the episode, but we are also told implicitly that, in the Nazi 
officer's view, the only significant difference between an African slave and a large black ape (forcing itself upon a white woman) is that one is real and the other fictional.

Most complicated (and interesting) of all, from an ideological perspective, is the film's use of Native American stereotypes. Lieutenant Raine informs his men in his opening speech that he is part Native American ${ }^{19}$, and that his goal is to make the Basterds into a crew of Apache warriors. Each member of his team must take 100 Nazi scalps, to instill fear in the German ranks. The film, then, portrays Native Americans as savage and fearful beasts, and then relates Jews to Native Americans (the aforementioned "muscle Jew"). But the simple stereotype of Native Americans as savages is subverted by the film because we are supposed to root for the savages (and even to sympathize with, and enjoy, their savagery) and by the fact that the film tells us that it ironically knows that it is using Native American stereotypes.

Basterds also self-consciously invokes the genre of spaghetti westerns, recalling their obsession with themes of justice and vengeance, as well as with stereotypes of Native Americans. ${ }^{20}$ In the same cellar tavern scene with the King Kong card, a German solider at another table has a card with "Winnetou" on it. Winnetou, a fictional character from German literature (by Karl May from the 1870s onward), and later German film (1960s) and television (1980s), is an Apache warrior. The character of Winnetou fits another well known stereotype, that of the noble savage (Winnetou is a sort of German version of Tonto, and Winnetou's European-American companion, Old Shatterhand, is a bit of a counterpart to the Lone Ranger). The Apache Winnetou clearly recalls the Apache Raine, a flourish that announces the film's knowledge of cinematic cowboys and Indians. The film thus uses Native American stereotypes while both subverting them and showing us that it is self-consciously doing so.

Characters in the film are hyper-concerned with their reputations and how they are depicted in the media; they are themselves obsessed with how they are stereotyped and ideologically represented. Lieutenant Raine and his crew wage psychological warfare with such dramatic flourishes as carving a swastika on the foreheads of the Germans they allow to escape and spread the word. Even Colonel Hans Landa (Christoph Waltz) is unduly proud of his reputation as the Jew Hunter, a reputation he attempts to control at the end of the film by describing (while negotiating the terms of his surrender) how he will be portrayed in history books. 
This reinforces the theme of how, and to what purposes, stereotypes are used and controlled.

\section{Elenchus and aporia}

The film, then, has a complicated relationship to ideology. Is it just a mishmash of popular culture references and a rationalization of stereotyping (stereotyping is okay if you do it ironically)? Perhaps the film's double use of ideology is simply vapid, its nod-and-wink use of stereotypes just an ironic joke. Perhaps we are supposed to have fun and participate in the ideology of the film while recognizing, on some level, that we are doing so. ${ }^{21}$

I will argue otherwise, but before doing so let us first examine the key features of the Socratic elenchus that I wish to draw upon. Socrates, according to the familiar story, sought an account or definition of the virtues such as piety, courage, and justice. ${ }^{22}$ Since he didn't know their definitions, he sought out those who thought they possessed such knowledge. ${ }^{23}$ Hearing their answers (such as Euthyphro's definition of the pious as that which is loved by the gods), Socrates would engage in a series of questions (elenchus, meaning, among other things, cross-examination, as in a legal setting) that would reveal the answers to be unsatisfactory (e.g., an answer conflicts with other things that the supposedly knowledgeable interlocutor believes). The result is that the interlocutor has been confronted with an inconsistency among his beliefs, which demonstrates that he lacks the knowledge and wisdom that he claimed to have. Usually the Socratic dialogues end inconclusively: we don't know which beliefs to give up (the original definition or the other beliefs with which it conflicts). Instead of making progress, we end in puzzlement or confusion (aporia). ${ }^{24}$

Let me highlight the three parts of this process that will be compared with Basterds. ${ }^{25}$ First, Socrates asks a question to solicit a claim to wisdom that his interlocutor purportedly possesses. I will call this step the setup. Second, Socrates asks a variety of other questions to draw out other commitments of the interlocutor. I will call these other commitments the background. Third, Socrates demonstrates an inconsistency between the setup and the background: all of these claims cannot be true. I will call this the dénouement. To continue the Euthyphro example, after Socrates hears from Euthyphro

SETUP: (1) the pious is that which is loved by the gods, i.e., loved by some god or other (6e-7a),

Socrates gets Euthyphro to recall that 
BACKGROUND: (2) the gods sometimes disagree; and (3) one act cannot be both pious and impious (6c; 7a-b).

Socrates then shows Euthyphro (in what I am calling the dénouement) that claims (1)-(3) form an inconsistent set and thus at least one of them must be false (7b-8b).

The method of elenchus is in the first instance negative: it demonstrates an inconsistency in someone's belief set. But the inconsistency does not tell us which belief is false. Even if all of Euthyphro's beliefs about piety cannot be true, we can't automatically conclude that the original setup claim, (1), is false. ${ }^{26}$ This negative result can, however, be of positive benefit: it can help us reexamine our beliefs about piety and eventually come closer to the truth; or it might be an end in itself, an intrinsically good thing to lead an examining and self-examined life practicing elenchus; or it might simply help us realize that like Socrates we too are ignorant, and in recognizing our own ignorance thereby come to be wiser (at least wiser in the sense of wisdom that the Delphic oracle attributes to Socrates) ${ }^{27}$ After all, if we are all ultimately ignorant, as Socrates seemed to think, then progress isn't getting the right theory, but coming to terms with our ignorance.

My interpretation of how ideology functions in Basterds, then, is this: the film cross-examines our attitudes toward ideology and finds them inconsistent, and this elenchus of our attitudes constitutes an important kind of progress. I will focus here on the dramatic climax of the film, but my points can be generalized to fit the ideological themes already mentioned. The climax takes place in a movie theater, where many of the key characters are watching the inaugural screening of the Nazi propaganda film, Nation's Pride. Tarantino intercuts close-ups of Hitler and Goebbels (Sylvester Groth)—watching Nation's Pride with wholehearted, almost child-like, enjoyment - with scenes of the film that they are watching, an amusingly vapid piece of propaganda showing Fredrick Zoller (playing himself) at the top of a tower gunning down countless enemies below. Nation's Pride intercuts that violence with close-ups of Zoller pausing in faux-dramatic fashion, after which he returns to the business at hand, shooting a dozen more people. The formal parallelism is striking, emphasizing the connection between the characters and their cinematic depictions, with close-ups of Zoller in the film matched with close-ups of Hitler and Goebbels, both intercut with lots of shooting.

Since the propaganda film Nation's Pride is so bad, viewers of Tarantino's film can't help but be amused that Hitler and Goebbels find such dreck entertaining. We laugh at them: enraptured with their own ideology, they don't recognize this 
piece of propaganda for the garbage that it is. Part of what makes Nation's Pride so bad is that its gratuitous rendering of violence is played as dramatically interesting. This is the subversive side of the theme I have been examining in the film's use of ideology: Basterds is showing its awareness of, and amused distance from, violent propaganda in war films at the same time that it mimics such films.

The deeper meaning to this subversive use of ideology emerges a few minutes later, when the two remaining Basterds carry out their plan of assassinating Hitler (and simultaneously Dreyfus/Mimieux carries out her plan of burning down the theater with all the Nazis inside). What is most striking about this dramatic climax is how over-determined its success is. Dreyfus/Mimieux and her accomplice have barred the doors to the main theater and lit an enormous pile of highly flammable celluloid that will quite assuredly burn the whole place down; the two Basterds have, independently, rigged the theater with a load of explosives sufficient to obliterate everyone inside. Before either of those feats of total destruction occurs, however, the two Basterds surprise Hitler and Goebbels in their box seats and kill them at close range. After tearing them to shreds, they then train their guns on the panicking crowd below, which is trying to flee the fire. But its efforts prove futile, since the doors are multiply locked and then barred (like an incinerator or gas chamber). Then, in an unmistakable reference to the scenes of Nation's Pride that we just saw, the two Basterds machine gun the crowd from above (just as Zoller, in the Nazi film, fired down from his perch on the soldiers below). But the Basterds' violence is even more gratuitous than Zoller's: the people they are shooting are already going to be burned to death by the (cinematically fueled) fire and blown to pieces by the explosives. The film gives their fierce faces both close-up and slowmotion emphasis, in which we see empty shells popping from the Basterds' guns like little exclamation points, one for each dead Nazi below. ${ }^{28}$

This moment is the culmination of the revenge fantasy against the Nazis, but it is also an alienating experience. We cannot help but enjoy the aesthetic force of the spectacle, and we also cannot help but realize that we are enjoying a gratuitously violent propaganda film quite similar to Nation's Pride. ${ }^{29}$ As both Mendelsohn and Leibovitz noted, the dynamic of ideology in the film likens us, and the Jewish heroes of the movie, to Nazis. The Socratic nature of this episode, I contend, is this. The film first elicits our condemnation of Hitler and Goebbels's enjoyment of the Nazi propaganda; that's the setup. Then the film asks us if we enjoy ideologically motivated spectacles ourselves. Our reactions witnessed 
throughout the film have been in the affirmative; that's the background. The dénouement finally comes when the film shows us, in this scene of movie-theater massacre, that our enjoyment is relevantly like theirs: we enjoy the wildly violent propaganda of our own ideology just as Hitler and Goebbels did theirs, and now that the tables have turned we are the ones cheering for the lining up of bodies in the incinerator. Before the elenchus we might easily think that we, like Euthyphro, have all the answers; the Nazis' enjoyment of ideology is problematic, whereas ours is not. We feel a moral superiority to the characters in the film-in fact the film invites us to relish in our supposed superiority - but then it exposes the continuity between us and the characters we deride. The film thereby reveals the tension in our attitudes toward ideology, and how shallow our supposed "wisdom" turns out to be..$^{30}$

Before continuing my analysis, let me consider an obvious objection. One might reject my understanding of the dénouement, and claim that we are not at all similar to Hitler and Goebbels because they are enraptured with the horrific ideology of Nazism, whereas our ideology is not horrifying. I think that there is little use, however, in attempting to justify our enjoyment of the film on moral grounds in this way, to defend our reaction as perfectly righteous given that Hitler and the rest of the Nazis got what they deserved. ${ }^{31}$ Such a maneuver simply misses the point of Ophüls' The Sorrow and the Pity. The question is not what sort of fate Hitler (or the rest of the Nazis) deserved. The question is do we want our reaction to the events of the Holocaust and Germany's attempt to dominate the world to be dictated by the same human tendencies that made such events possible. Those tendencies include the common inclination to exert coercion and control through propaganda and misinformation, demonization and stereotyping of the "other", and to enjoy the visceral pleasure of seeing the "other" (once having been demonized) executed, disfigured, and immolated in orgasmic gore. ${ }^{32}$ Those are the very tendencies that we condemn in the Nazis and yet enjoy in Tarantino's film several seconds later.

Ophüls has already argued that the correct reaction to the Nazi ideology is not ignorant flight to some competing ideology. Recall Ophüls' treatment of Raymond Guyot: the correct reaction to the Nazis' "cleansing" isn't adopting our own style of cleansing; it is putting a stop to cleansing per se. I therefore find it difficult to de-problematize our enjoyment of the climax of Tarantino's film. Consider also the fact that, with the death of Hitler and Goebbels, the Basterds have 
accomplished their mission; when they train their guns at the panicking crowed below they are executing many non-combatants, whose deaths serve no justifiable purpose; the Basterds then are akin to the members of the French resistance who, caught up in the frenzy, merely continued the cycle of violence that they were supposed to be stopping. ${ }^{33}$

If that is right, then our disdain for Hitler and Goebbels's enjoyment of Nation's Pride boomerangs as we realize that we should disdain our own enjoyment of Tarantino's film. We are like Euthyphro, who cannot help but assent to principles which reveal a contradiction in his attitudes. In our response to Basterds, we are confronted with a contradiction in our attitudes toward the ideology of the film: we endorse it, and yet we don't; we disdain our own endorsement of it as we simultaneously do so. In effect we don't know what to do or say, just as Euthyphro doesn't. We have reached aporia; puzzlement reigns. ${ }^{34}$ On my understanding of the film it is key that the resulting aporia be genuine: we really don't know what to think or feel regarding the ideological themes of the film. It is therefore essential to my interpretation that easy solutions are not forthcoming.

Aside from fleeting moments of discomfort, it is all too easy to be drawn in by Tarantino's storytelling and the aesthetic spectacle of the film. It feels guileless to simply disavow what I am calling the background, our willing participation in the film's ideological play. As Richard Robinson comments on the Socratic dialogues, the answers to the background questions "seem obvious and inescapable. Socrates usually phrases them so that the natural answer is yes; and if you say anything else you are likely to seem irrational or at least queer. In other words, they are not so much requests for information as demands for an assent that cannot very well be withheld" (Robinson 1953: 7). Similarly, our aesthetic enjoyment of the film cannot very well be withheld, even if we are aware of the uncomfortable situation it puts us in; nor do we stop condemning the devices of Nazi ideology that the film depicts. Because both of these attitudes are robust, the film problematizes our enjoyment of itself, and therein lies the aporia. If we could stop enjoying the film, or if we could defend our enjoyment of it as morally righteous, the aporia would disappear, but I find these easy solutions equally unsatisfying. It's not even clear to me that we should stop enjoying the film, could we do so. By confronting us with this puzzle, the film conveys to us our lack of wisdom and spurs us to think more deeply about ideology. ${ }^{35}$

Although I have invoked Ophüls in my analysis above, I think that 
Basterds's unique achievement is that it cross-examines us about our susceptibility to ideological artifacts. A key feature of Socratic elenchus is that the interlocutors stand behind what they say. Socrates wasn't interested in some hypothetical or sophistic discussion of what one might think about so-and-so; he wanted to hash out the details of what one actually thinks about justice or piety. ${ }^{36}$ The inconsistencies he turns up are inconsistencies in one's actual belief set; that gives them their bite. Similarly, Basterds calls forth our actual emotions and attitudes-our bloodthirsty desire for revenge and our enjoyment of the propaganda that fulfills that desirewhich it then cross-examines. Ophüls' film has no corresponding mechanism. It is true that Ophüls' film exposed tensions in the attitudes towards resistance and collaboration, vengeance and justice, of many of the French in the 1960s, but Ophüls' film doesn't elicit those attitudes from us; either we already have them or we don't. Tarantino's film, though, makes us complicit by wringing the enjoyment out of us. It has a first-person effect that The Sorrow and the Pity lacks. ${ }^{37}$

This difference is even clearer now that time has passed and Ophüls' film is no longer directed at its historical audience. For contemporary viewers, it is all too easy to think, while viewing Ophüls' film, that the moral failure belongs to someone else (the Nazis, the resistance fighters who continued the cycle of violence, the passive citizens who did nothing about it, etc.). We feel no tension, but rather a smug, liberal feeling of moral superiority. At best, we might wonder whether we would be courageous enough to do the right thing were something similar to happen to us. But such abstract, hypothetical worries are less disconcerting when compared to the first-person problematization of our attitudes created by Tarantino's film. Consider, by contrast, a viewer of Basterds 50 years from now: as long as the film still "works", it will still inculpate the viewer for her enjoyment of the spectacle and, one supposes, generate the same sort of tensions that it does for us. This personal aspect is a significant part of the aporia generated by the film. We cannot simply think that some other person cannot resolve her attitudes toward ideology; that thought is neither surprising nor interesting. Rather we must realize that we cannot resolve our own attitudes toward ideology, and that is genuinely puzzling.

It is not just puzzling, because confidence in one's own moral and ideological perspective comes naturally to us all. More to the point, the film has invited us to express a hubristic confidence in our own moral and ideological perspective. Recall, e.g., the King Kong scene. The German officer's attitudes towards 
Africans are clearly racist. We disdain him, but we can also explain his racism, given that it is inherent in the Nazi ideology. Our disdain for him expresses our own superiority: we laugh at his attitudes, confident that we are nothing like him. We have an ironic distance that comes along with our sense of superiority. What we fail to realize is that the film has an additional ironic distance from us; once we are subject to the elenchus we see our confidence exposed for the hubris that it is (cf. Euthyphro's great sense of self-confidence). Perhaps our situation would not be so puzzling if we never thought that we had any wisdom in the first place, but true to the form of elenchus the film already has, in a sneaky way, cut us off from such a humble retreat.

The first-personal nature of the aporetic experience also reveals the deeper (and easily missed) meaning of the final scene of the film, when Raine marks Landa's forehead with a swastika, that icon of Nazi ideology. Until that moment, the film has portrayed Landa as cool and in control. He is often in a position of superior knowledge to other characters in the film (just as we spectators are often in such a position), and when he isn't he quickly uses his powers of reason to infer what he needs to know. When Landa (an Austrian) finally reveals his plan to betray the Germans, we learn that he has even been in a position of superior knowledge to us, the spectators. ${ }^{38}$ We also learn that Landa has been engaged in a sort of ideological play of his own - he isn't committed to the ideology of Nazism, but he is quite willing to use that ideology for his own ends. ${ }^{39}$ Landa has had his own ironic distance from other characters in the film, just as we have had ours (see, e.g., Landa's Italian conversation with the Basterds).

When Landa gets marked, however, the film punishes this conceited irony and play with ideology. Notice how Tarantino graphically renders the cutting of Landa's forehead, on-screen violence that is much more difficult to watch than the bloodbath in the theater. When Landa is cut we squirm in our seats, and rightly so, because we are metaphorically being marked as well for our own use of ideology. Immediately after Raine carves the swastika, the film cuts to a point-of-view shot from Landa's perspective, heightening the connection between him and us. Raine and Utivich look down on him/us as the film ends and Raine declares, "You know somethin', Utivich? I think this just might be my masterpiece." Indeed, this marking of him/us is the masterful achievement of the film. Landa's comeuppance is a metaphor for our own, revealing the deeper connection between this climax of the film and the movie-theater climax we just witnessed. ${ }^{40}$ 
At this point we might even recall the earlier scene when, in a moment of contemplation, the character Dreyfus/Mimieux pauses in front of a window shaped like a giant eye - the examining eye of the film. The eye reflects the character's red-clad image so that she is shown twice on the screen; the eye reveals her double life as Shosanna Dreyfus and Emmanuelle Mimieux. ${ }^{41}$ The eye takes up so much of the screen, though, it is as if it is looking into, examining, us, the spectators. (And what the eye reflects back at us are the trappings of nefarious ideology, two swastikas.)

\section{Authorship}

There is an important disanalogy between Plato's dialogues and Basterds. In Plato's works there is a character, Socrates, who actually performs an elenchus on other characters; in a secondary way the dialogues, or the dialogues' author, Plato, performs an elenchus on us, the readers. ${ }^{42}$ In Basterds there is no such Socratic character (although there is lots of good cross-examining banter). Rather, on my interpretation, the film itself plays the role of Socrates; or, to put it another way, there is just the secondary elenchus of us, the spectators, by the film. Let me clarify that I am attributing this elenchus to Tarantino's film itself, not to Tarantino the filmmaker. The reason for my doing so is that I agree with Stephen Mulhall and Daniel Frampton that films themselves can be considered to be autonomous entities capable of doing philosophy (see Mulhall 2008 and Frampton 2006). ${ }^{43}$ Whether Tarantino personally planned to expose tensions in our attitudes toward ideology I consider an interesting question, but one that is ultimately tangential to the philosophical significance of the film argued for in this essay. ${ }^{44}$

Tarantino's own understanding of the film and his intentions in making it are, characteristically, hard to read. On the one hand he seems to embrace the aesthetic spectacle and simplistic enjoyment of the film. He wanted to make a fun war movie, not an anti-war war movie: "And this goes against all the ponderous, anti-war, violin-music diatribes that we've seen in war movies since the ' $80 \mathrm{~s}$. I'm not trying to be pissy about the movies of the past 30 years. It's just that there's been a one-note concentration on victimization" (interview with Huddleston 2009). Tarantino clearly means for us to enjoy his use of stereotypes and ideology: "Over the years, when I was coming up with the idea of the American Jews taking vengeance, I would mention it to male Jewish friends of mine, and they were like, 'That's the movie I want to see. Fuck that other story, I wanna see this story.' Even I get revved up, and I'm not Jewish" (interview with Taylor 2009). 
On the other hand, Tarantino is well aware of the complex meta-cinematic references of his film.

On the one hand I'm making a revisionist history of the war, but I'm also dealing with characters who deal with revisionist histories of the war. I'm also looking at the tragedy of genocide. I'm dealing with the Jewish genocide in Europe, but my Jews are going native and taking the roles of American Indians - another genocide. Then there's a "King Kong" metaphor about the slave trade, that's another genocide. (Interview with Huddleston 2009)

He is also aware of the ideological inversions that his film enacts, the inspiration of which he credits to The Dirty Dozen: "The metaphor is not lost, you know, in that, via these film prints and via her cinema, Shosanna is intending to put the Nazis in an oven and create her own final solution" (interview with Sordeau 2009).

Finally, he also seems to understand that the climax of his film problematizes the audience's enjoyment of it: "I set up scenes and I jerk you off to have a climax. And in this movie I jerked you off and I fucked with the climax... At some point those Nazi uniforms went away and they were people being burned alive. I think that's part of the thing that fucks with the catharsis. And that's a good thing" (interview with HEEB 200945). Whether these reflections reveal his deep understanding of ideology or are merely passing thoughts, however, I will not hazard a guess. ${ }^{46}$

\section{A Little Something You Can't Take Off}

This essay has attempted to counter interpretations of Inglourious Basterds that see the film as superficially hip, morally monstrous, or just an aesthetic spectacle that we are meant simply to enjoy in that contemporary ironic way in which we enjoy any bit of "postmodern" culture. What the latter view gets right is that we are supposed to enjoy the aesthetic spectacle of Basterds, but the ironic role of stereotypes in the film doesn't simplify that enjoyment; it problematizes it. The ironic use of ideology in the film adds depth because it catches us in a contradiction: it functions as a cross-examination and leaves us in aporia. Of course, we can always flee from this sort of aporetic experience, just as Socrates's interlocutors often fled from his questions by the end of the dialogue. ${ }^{47}$ But if we take the time to think about it, we realize that we lack the wisdom that we blithely thought we possessed, the (supposed) wisdom of those who think they can easily recognize and avoid the pernicious, unjust use of ideologies. We all condemn the 
Nazi ideology, and thus take ourselves to be wise. But then the film forces us to recognize that we cannot help but participate in ideological spectacles ourselves, and enjoy doing so, in a fashion that is strikingly similar to the way we see the characters in the film participating in their ideology. Basterds reveals this tension, and demonstrates that our attitudes aren't even consistent, let alone true. Whether we are now able to revise our attitudes towards the truth, or whether we should join company with Socrates and admit our ultimate ignorance, is a question we must now try to answer for ourselves.

\section{Ian Schnee}

\section{Notes}

1 I would like to thank Paul S. Loeb, Eric Bain-Selbo, Alan Code, Christopher Grau, Andy Engen, Ryan Parker, Robert von Dassanowsky, Daniel Shaw, an anonymous reviewer, and audiences at the University of Puget Sound, at the 2011 Eastern Division Meeting of the APA and at Western Kentucky University.

2 See, e.g., Robert von Dassanowsky (ed.), Quentin Tarantino's Inglourious Basterds: A Manipulation of Metacinema (London: Continuum, 2012).

3 Tarantino: "But I like the idea that it's the power of cinema that fights the Nazis. But not even as a metaphor-as a literal reality" (interview with Henri Sordeau, "Quentin Tarantino talks Inglourious Basterds-RT Interview," Rotten Tomatoes (2009), http://www.rottentomatoes. com/m/inglourious_basterds/news/1837048/quentin_tarantino_talks_inglourious_basterds_rt_ interview).

4 Daniel Mendelsohn, “'Inglourious Basterds': When Jews Attack,” Newsweek Magazine (2009), http://www.thedailybeast.com/newsweek/2009/08/13/inglourious-basterds-when-jews-attack. html.

5 "Do you really want audiences cheering for a revenge that turns Jews into carboncopies of Nazis, that makes Jews into 'sickening' perpetrators?" (Mendelsohn 2009).

6 Leil Leibovitz, "Inglorious Indeed," Tablet Magazine (2009), http://www.tabletmag.com/ jewish-arts-and-culture/14057/inglorious-indeed.

7 Eric Kligerman, "Reels of Justice: Inglourious Basterds, The Sorrow and the Pity and Jewish Revenge Fantasies," in Dassanowsky (ed.) 2012.

8 See, e.g., Nelly Furman, "Viewing Memory Through Night and Fog, The Sorrow and the Pity and Shoah," Journal of European Studies (2005) 35 (2): 169-185.

9 This former German soldier seems rather smug as he sits in lederhosen drinking beer in what seems to be a Bavarian bierhaus complaining about the French not being adequately sympathetic to their German occupiers, raising complex issues of stereotyping and ideology that will be so important to Tarantino's film.

10 "Like A Nation's Pride, Tarantino's film is a bit of shallow propaganda, promoting not some totalitarian ideology but a worldview in which cool trumps consequence, nothing is real, and everything is permitted" (Leibovitz 2009).

11 "As Tarantino seduces us with promises of revenge, a debt of judgment is passed on to the spectator, who must deconstruct the film's semiotics haunted by other filmic cues as well as historical scenes of violence" (Kligerman 2012: 158).

12 Tarantino: "What makes me sit down to start writing is a genre that I'm interested in tackling. But once I start, I explode the borders of that genre" (interview with Tom Huddleston, "Quentin Tarnation: Interview," Time Out: London (2009), http://www.timeout.com/film/features/showfeature/8395/quentin-tarantino-interview.html). 
13 The relation of Tarantino's film to Castellari's is particularly interesting; Castellari was already, in 1978, ironically invoking genre conventions of Aldrich's The Dirty Dozen of 1967. Tarantino originally thought of remaking Castellari's film, but eventually retained none of the content save the title. Of course, he saved the title only in a sense, since, as many have remarked, Tarantino (semi-purposefully) misspelled it and dropped the "The".

14 Also see Dassanowsky's comparison of Basterds to forerunners Castle Keep (Sydney Pollack, 1969) and Escape to Athena (George Pan Cosmatos, 1979) (Dassanowsky, "Introduction: Locating Mr. Tarantino or, Who's Afraid of Metacinema?" in Dassanowsky (ed.) 2012, xviixviii).

15 Tarantino's film, of course, was also released during a period of international conflict (wars in Iraq and Afghanistan; the "war on terror" instead of the cold war). See also Tarantino on propaganda films and influences: "Well, y'know, it was the Dirty Dozen idea that set me down to start writing in the first place" (interview with Sordeau 2009); "I was very influenced by Hollywood propaganda movies made during World War II. Most were made by directors living in Hollywood because the Nazis had taken over their countries, like Jean Renoir with This Land Is Mine, or Fritz Lang with Man Hunt, Jules Dassin with Reunion in France, and Confessions of a Nazi Spy-movies like that" (interview with Ella Taylor, "Quentin Tarantino: The Inglourious Basterds Interview," The Village Voice (2009), http://www.villagevoice.com/2009-08-18/news/ quentin-tarantino-the-inglourious-basterds-interview).

16 I don't mean to suggest that those films are simplistic or non-ironic, since they self-consciously employ genre conventions of 1950s war movies like Bridge on the River Kwai (David Lean, 1957), Attack (Robert Aldrich, 1956), Stalag 17 (Billy Wilder, 1953), and The Steel Helmet (Samuel Fuller, 1951). Just compare Aldrich's 1956 Attack and 1967 The Dirty Dozen.

17 Nation's Pride is no Triumph of the Will remake, but it is accompanied by numerous Leni Riefenstahl references.

18 To mention just a few; the list goes on: Americans, Germans, Italians, British, French, AfroFrench, Nazis, etc.

19 And part Southern hillbilly moonshiner, though that stereotype gets turned on its head as well by Raine's being the Southern hillbilly who is incredibly verbose and a champion of minority rights.

20 This confluence of stereotypes connects the genocide of Jews by the Nazis (and their collaborators) with that of Native Americans by the American government.

21 E.g., see Tarantino's interview with Taylor (2009). Tarantino's own understanding of the film is discussed in section 6 below.

22 At least, Socrates as we find him in Plato's early dialogues, such as Apology, Euthyphro, Crito, and Laches (all in The Dialogues of Plato, Volume I, trans. B. Jowett (New York: Random House, 1937)). Also see Aristotle: "Socrates, however, was busying himself about ethical matters and neglecting the world of nature as a whole but seeking the universal in these ethical matters, and fixed thought for the first time on definitions" (Metaphysics 987b1-4, in The Basic Works of Aristotle, ed. Richard McKeon, trans. W. D. Ross (New York: Random House, 1941)).

23 See the account of this process in the Apology, e.g., 22b-23b.

24 Nice examples of aporia are Euthyphro (15c) and Protagoras (360d-361d; also in Jowett 1937). The status of Protagoras as an early or Socratic dialogue can be questioned; I make no claims about its accuracy regarding the historical Socrates, but I still consider it a prime example of Socratic elenchus.

25 Here I am drawing on Hugh Benson, "Socratic Method," in The Cambridge Companion to Socrates, ed. Donald R. Morrison (Cambridge: Cambridge University Press, 2011) and Socratic Wisdom: The Model of Knowledge in Plato's Early Dialogues (New York: Oxford University Press, 2000); also see Gregory Vlastos, Socratic Studies (Cambridge: Cambridge University Press, 1994).

26 I am following Benson $(2000,2011)$ in understanding the method of elenchus in this way (viz., that Socrates does not automatically conclude the opposite of the setup belief he examines). This is not uncontroversial, however. For the opposing view see Vlastos's discussion of "standard elenchus" in Vlastos 1994 and "The Socratic Elenchus," The Journal of Philosophy (1982) 79 
(11): 711-714.

27 Apology 21a and 23b.

28 Thus prima facie both Basterds's violence itself is more gratuitous and its representation of violence is more gratuitous than that of Nation's Pride (cf. the Hitler face shot in Basterds). Ultimately I do not think Basterds's representation of violence is gratuitous, however, because it serves a key role in the elenchus, but that role is something one must figure out on the basis of its prima facie gratuitousness (cf. the way one figures out a Gricean implicature; see H. P. Grice, "Logic and Conversation," in The Logic of Grammar, eds. D. Davidson and G. Harman (Encino: Dickenson, 1975)).

29 Tarantino's film is therefore best viewed on the big screen in a theater. The close-ups of Hitler and Goebbels are from the vantage point of the person sitting next to them (e.g., Goebbels's glances at Hitler). One only has to look at one's neighbor sitting next to one, as the Basterds fire down at the crowd, to have an exactly parallel experience of a close-up of one's neighbor (and, in a sense, of oneself).

30 An interesting question is how the film could convey or indirectly communicate this message, especially when the film seems to simply invite our straightforward enjoyment of it. One answer is Platonic and Socratic irony. As many commenters have noted, Socrates often makes claims that seem insincere (for discussions see Richard Robinson, Plato's Earlier Dialectic, 2nd edition (Oxford: Clarendon Press, 1953), Ch. 2 and Alexander Nehamas, The Art of Living (Berkeley: University of California Press, 1998), Ch. 1-3). For example, he claims to want to be Euthyphro's student (5c), whereas it seems clear that he doesn't actually think that Euthyphro has the answers he seeks. See my elaboration of irony below. In the passage in the main text above I draw on Nehamas 1998: 32.

31 One could even invoke familiar philosophical thought experiments: how could there be an absolute prohibition on any act, be it the use of violent propaganda or even torture, if one's committing that act would prevent some other greater measure of it?

32 Contrast the role of aporia and elenchus as described by David Wolfsdorf: "The early dialogues' sweeping criticism of Athenian culture is a critique of established authority. This critique targets the conventional and traditional values of institutions and practices such as the Athenian democracy, the Thirty's violent regime, sophistry, and Attic drama. It also concerns the manner in which the values of these institutions and practices are imposed and adopted. The early dialogues emphasize that, whether one is persuading or being persuaded, conviction should result not from grounds such as force, threat, cajolery, habit, or rhetoric, but from understanding and rational argumentation" ("Interpreting Plato's Early Dialogues," in Oxford Studies in Ancient Philosophy, Volume XXVII, ed. David Sedley (Oxford: Oxford University Press, 2004), 23).

33 Also notice the coincidence noted by Kligerman that Basterds was released at the same time as the Abu Ghraib scandal was in the news (Kligerman 2012: 147). "What's that American expression ... 'If the shoe fits...'?"-Hans Landa.

34 The reader might have now noticed why I have drawn on Benson's understanding of the argumentative functioning of elenchus rather than Vlastos's (see my footnote 26 above). Benson holds that Socrates does not automatically infer the falsity of the purported bit of wisdom he is examining, whereas Vlastos holds that Socrates in "standard elenchus" does make such an inference (how such an inference could be justified is an interesting philosophical problem Vlastos raised). Tarantino's film, in my opinion, is Bensonian, rather than Vlastovian: we should not automatically infer that we were wrong to condemn the Nazis' use of ideology; nor should we automatically infer that our own enjoyment of ideological devices is equally condemnable. The film merely shows us the tension between our attitudes, which we must now confront.

35 Discussing a passage in the Meno, Robinson notes: "The elenchus changes ignorant men from the state of falsely supposing that they know to the state of recognizing that they do not know; and this is an important step along the road to knowledge, because the recognition that we do not know at once arouses the desire to know, and thus supplies the motive that was lacking before. Philosophy begins in wonder, and the assertion here made is that elenchus supplies the wonder" 
(Robinson 1953: 12).

36 E.g., see Protagoras 331c-d, Gorgias 471d and 495a-c, and Laches 193c. For discussion of potential counterexamples to this doxastic commitment, see Benson 2011.

37 Note that I am not claiming that Basterds is a "better" film than The Sorrow and the Pity, whatever that might mean. Rather, I am arguing that it offers a fascinating and challenging perspective on ideology, Nazism, and the Holocaust that does not merely duplicate the insights of Ophüls' film. The two films function in distinct ways, which makes the comparison of them all the more fruitful.

38 Indeed, in the dining scene perhaps Landa even realizes that Mimieux is actually Dreyfus, but he doesn't let on because he is already thinking of how to use that knowledge to his advantage (the film doesn't telegraph this knowledge, the "milk" line just hints at it). I do not claim, however, that the film portrays Landa in a uniformly superior manner. We see that his suaveness is sometimes studied and his manners sometimes artless. Landa's personality involves much deception, and we even get to see how it sometimes involves self-deception. He believes he is funnier than he is. As I read it, that is a perfect metaphor for our own self-deception as spectators. This is a theme with Socratic roots that deserves elaboration in further work (cf. Nehamas 1998: Ch. 1).

39 It is interesting to question how sincere Landa's apostasy is; I do not mean to claim that he lacks racist or bigoted attitudes, etc.

40 Notice also how Mendelsohn and Leibovitz's antipathy to the film unintentionally demonstrates its Socratic effect. Mendelsohn and Leibovitz react so negatively because they feel the discomfort that comes from being likened to a nefarious ideology. They fail to credit the film, though, with generating their discomfort in a profound way and to profound effect. Instead, they get mad at Tarantino, gadfly on the mighty steed of Hollywood, just as Socrates's interlocutors often got mad at him (see Apology 21d-e and 22e-23e). Unlike their reactions to the film's complex use of ideology, Kligerman sees the way that the film implicates us, the viewers. Kligerman writes, "Despite Jeffrey Wells' description that this scene [the Bear Jew with baseball bat] is 'morally disgusting,' I contend it operates by means of a moral complexity that implicates our spectatorship. While the spectator may be drawn to a film whose trailer exclaims 'we will be doing one thing only ... killing Nazis,' the satisfaction of vengeance is compromised by the visceral affect of horror or repulsion that is part of the debt owed for our spectatorship" (Kligerman 2012: 152).

41 The significance of this image goes even further. Mimieux's face looks as if it is additionally reflected, and thus shown a third time, but actually this third image is a woman's face on a movie poster in the background; the superimposition of Mimieux's image on the movie poster signifies her second life (as Mimieux, her false identity while on the run from the Nazis) as an "act".

42 Nehamas 1998: 32-45.

43 Mulhall, On Film, $2^{\text {nd }}$ Edition (London: Routledge, 2008); Frampton, Filmosophy (London: Wallflower, 2006).

See, e.g., Frampton 2006: 46. I do not, however, follow all of Frampton's theses of filmosophy; I agree with him concerning the importance of a film's overall emotional impact (this impact I think plays a key role in the functioning of Basterds), but as evidenced in this essay I do not eschew what Frampton considers "technist" terminology and analysis. There are additional reasons as well to not attribute the elenchus to Tarantino himself. One is that filmmaking is a collaborative enterprise, and one might worry about the overreliance on auteur theory latent in such an attribution (though the objection might be mitigated somewhat by the great amount of creative control Tarantino has over his work; auteur theory in general must be false, but a highly qualified version of it might be plausible for writer-directors like Tarantino). A second reason concerns authorial distance and the "intentional fallacy". I will not pursue the value of these points further, however, since I take the reason given in the main text above to be decisive.

44 Which is not to say that as I see it a filmmaker's intentions are wholly irrelevant to the meaning of a film. On this issue also see the work of Berys Gaut-Art, Emotion and Ethics (Oxford: Oxford University Press, 2007) and A Philosophy of Cinematic Art (Cambridge: Cambridge University Press, 2010)- especially 2010: 152-196. Gaut's work on aesthetics and morality 
is particularly pertinent given the moral dimension of our condemnation of certain uses of ideology as well as the moral dimension of Socratic elenchus (its contribution to living well). It is interesting to contrast my analysis of elenchus in Basterds with Gaut's discussion of the "seduction strategy" (Gaut 2007: Sections 8.3-8.4), but that must await further work.

45 "Quentin Tarantino Dealt with Hitler, But Can He Deal with the Holocaust Museum?" HEEB (2009), http://heebmagazine.com/quentin-tarantino-dealt-with-hitler-but-can-he-deal-with-theholocaust-museum/4566.

46 For interesting thoughts pertinent to Tarantino on authorial irony in film see George E. Toles, $A$ House Made of Light: Essays on the Art of Film (Detroit: Wayne State University Press, 2001). Thanks to Christopher Grau here.

47 E.g., see Euthyphro's hasty departure at $15 \mathrm{e}$. 